\section{Lead preparations in Ayurvedic medicines}

Sir

Keen et $a l^{1}$ presented a typical case of hepatitis after using an Ayurvedic preparation as a remedy for diabetes. The authors did not give the details of the drug dosage, trade name, pharmaceutical dosage form or source.

Ayurveda lays much emphasis on the purifactory aspects of its drugs which are mainly of herbo-metallo-mineral and animal origin, some of which are highly toxic when taken in their crude or natural form. After specific purifactory processes, metals are subjected to treatments such as impregnation and trituration with other herbal drugs and are eventually subjected to different types of heat treatment, using conventional methods. The heavy metals are brought into colloidal form after incineration. For example, the leadcontaining preparation, sastiputa naga bhasma is subjected to 60 cycles of incineration.

Studies were carried out at Gujarat Ayurveda University ${ }^{2}$ and Banaras Hindu University ${ }^{3}$ in India on lead ash prepared by the different methods used to make Ayurvedic medicines and their use in the treatment of various diseases.

Experimental studies showed that $\mathrm{Pb}$, $\mathrm{PbO}, \mathrm{PbSO}_{4}$, and $\mathrm{PbS}$ preparations available in the market are toxic. X-Ray diffraction analysis proved that the Ayurvedic preparation sastiputa naga bhasma is chemically $\mathrm{PbS}$; it is nevertheless reported to be non-toxic in experimental and clinical studies. ${ }^{4}$ Depending on the preparation, the lead content varies from $14.5 \%$ to $68.14 \%$. The lead content of sastiputa naga bhasma reported by Nagaraj was $64.24 \%$ whereas in their sample of the drug Keen et al $^{1}$ reported a lead content of $19 \%$.

The experimental study on rats and the clinical trials conducted proved that the Ayurvedic lead preparations are non-toxic when the dose is below $6 \mathrm{mg} / 100 \mathrm{~g}$ body weight. ${ }^{5}$ The prescribed dose in the treatment of diabetes is $30-120 \mathrm{mg} /$ day in case of an adult. ${ }^{6}$ The results of the clinical trials carried out with sastiputa naga bhasma and other hypoglycaemics are given in the table to get a clear picture of its action on diabetes.

ACHARYA RAVINARAYAN

Department of Dravyaguna,

Institute for Post-Graduate Training and Research

Gujarat Ayurveda University, famnagar 361008 India KP SKANDHAN Department of Physiology, MP Shah Medical College, famnagar 361008 India

1 Keen RW, Deacon AC, Delves HT, Moreton JA, Frost PG. Indian herbal remedies for diabetes as a cause of lead poisoning. Postgrad Med I 1994; 70: 113-4.

2 Dave RA. A comparative study of nagabhasma with special reference to different media. MD thesis submitted to Gujarat Ayurveda University, Jamnagar, 1991.

3 Sing M. Pharmaceutical and experimental study on nagabhasma with special reference to its toxicity and testicular regeneration. MD thesis submitted to Banaras Hindu University, 1984.

4 Nagaraj T. Pharmaceutical study on naga (lead metal) and its role in the management of diabetes mellitus. PhD thesis submitted to Banaras Hindu University, 1992

5 Sing M. Studies on naga bhasma with reference to its rasayana effect. $\mathrm{PhD}$ thesis submitted to Banaras Hindu University, 1992.

6 Sharma S. Rasatarangani. Banaras: Motilal

Banarasidas, 5th edn, 1994, p 466.
Table Results of clinical trials with sastiputa naga bhasma

\begin{tabular}{ll}
\hline Groups & $\begin{array}{l}\text { Fall in blood sugar } \\
\text { level (\% of cases) }\end{array}$ \\
\hline $\begin{array}{l}\text { Sastiputa naga bhasma } \\
\text { Sastiputa naga bhasma and } \\
\text { hypoglycaemic drugs }\end{array}$ & $50^{\star}$ \\
\hline
\end{tabular}

*No hypoglycaemia was reported

This letter was shown to the authors who reply as follows:

Sir,

Ravinarayan and Skandhan claim that lead, present as PbS, in Ayurvedic medicines is non-toxic, because of specific purification processes which include multiple incinerations. The evidence cited in support of this claim is contained in four unpublished theses submitted for either $\mathrm{MD}$ or $\mathrm{PhD}$ degrees between 1984 and 1992. However, no treatment can alter the facts that lead sulphide is soluble in acids, including gastric secretions, and that soluble lead is toxic.

Ravinarayan and Skandhan report a prescribed dose of $30-120 \mathrm{mg} /$ day of an Ayurvedic medicine for the treatment of adult diabetes. The intake of lead from this medicine would be $6-24 \mathrm{mg} /$ day-assuming a lead content of $20 \% \mathrm{w} / \mathrm{w}$. Sustained intakes by adults, of more than $1 \mathrm{mg} /$ day will lead to increased blood-lead concentration and adverse metabolic, functional and clinical effects. ${ }^{1}$ Therefore, one would expect to see adult poisoning with prolonged intakes of the above medicines. This is what we observed and reported. ${ }^{2}$

Our patient had a limited supply of a medicine obtained indirectly from India, and had taken the preparation for a relatively short period, about six weeks. Although it was not possible to establish and document the dose taken, the similarity between the unusual lead isotopic compositions of the substance and the patient's blood, indicated this to be the source of lead poisoning.

Our conclusion, that such medicines are not safe, remains unaltered.

HT DELVES

Department of Clinical Biochemistry, Southampton General Hospital, Southampton SO9 $4 X Y$, UK PG FROST

Department of Chemical Pathology, Central Middlesex Hospital, London NW10 7NS, UK

1 Chisolm JJ Jr. Lead poisoning. Sci Am 1971; 224: 15-23

2 Keen RW, Deacon AC, Delves HT, Moreton JA, Frost PG. Indian herbal remedies for diabetes, as a cause of lead poisoning. Postgrad Med F 1994; 70: 113-4

\section{Streptococcus mitis causing epidural abscess}

Sir,

We report a case of spinal epidural abscess caused by Streptococcus mitis. A 57-year-old haemophiliac man presented to accident and emergency with neck pain of six days duration. It radiated to the shoulders, was worse

\begin{tabular}{|l|}
\hline Spinal epidural abscess \\
\hline - Staphylococcus aureus $52-95 \%$ \\
- coagulase-negative staphylococci \\
- aerobic Gram-negative rods \\
- streptobes \\
\hline
\end{tabular}

with movement and had been getting gradually worse. Examination revealed a temperature of $38^{\circ} \mathrm{C}$. Neck movements were restricted. Muscle spasm was present and there was mild tenderness over C4-C5. Peripheral white cell count was $11.8 \times 10^{9} / 1$ and the erythrocyte sedimentation rate was $70 \mathrm{~mm} / \mathrm{h}$. Blood cultures and cervical X-rays were taken. A bleed was thought to be the cause of the symptoms although the fever was difficult to explain. The X-ray showed diffuse degenerative changes of the cervical vertebrae but no sof tissue changes suggestive of haemorrhage or infection. The patient was given 1500 units of factor VIII, but despite a further two doses over 24 hours there was no improvement. His temperature continued to fluctuate, sometimes up to $39^{\circ} \mathrm{C}$ and he had occasional rigors. On day three of admission both bottles of blood cultures grew Staphylococcus epidermidis and an alpha-haemolytic streptococcus later identified as Streptococcus mitis. These organisms were felt to be probable contaminants and repeat cultures were performed which proved negative. The following day he developed weakness and numbness of the right arm and MRI scan revealed an anterior cervical abscess over $\mathrm{C} 4-\mathrm{C} 6$ vertebrae. This was drained under factor VIII cover. The pus and a swab from the abscess site grew a heavy pure growth of Streptococcus mitis. This proved a sensitive organism and he was treated with benzylpenicillin $1.2 \mathrm{~g}$ iv four hourly and metronidazole $400 \mathrm{mg}$ orally three times a day for two weeks followed by benzylpenicillin alone for a further 10 days when he developed a maculopapular rash. The penicillin was replaced by erythromycin $500 \mathrm{mg}$ orally four times daily for two weeks. His temperature settled and he made a good recovery.

The microbiology of spinal epidural abscesses is dominated by $S$ aureus. ${ }^{2,3}$ Standard therapy should involve surgical drainage where possible as well as prolonged antibiotic therapy (4-6 weeks). We chose benzylpenicillin and metronidazole in case there was an anaerobic organism that failed to grow. Erythromycin is a suitable alternative in cases of allergy. We believe this is the first reported case of spinal epidural abscess caused by Streptococcus mitis, and illustrates the importance of sampling at operation to obtain the correct microbiological diagnosis.

MJ MARTIN PYC LEE

Department of Microbiology, St George's Hospital, London SW17 OQT, UK

1 Baker AS, Ojemann RG, Swartz MN, Richardson EP Jr. Spinal epidural abscess. N Engl f Med 1975; 293: 463-8.

2 Heuser AP. Non-tuberculous spinal epidural infections. N Engl f Med 1948; 239: 845-54.

3 Danner RL, Hartman BJ. Update of spinal epidural abscesses: 35 cases and review of the epidural abscesses: 35 cases and review of
literature. Rev Infect Dis 1987; 9: 265-74. 